\title{
Circulating 'big' insulin in protein-energy malnutrition
}

\author{
BY DOROTHY J. BECKER, PENELOPE J. MURRAY, \\ J. D. L. HANSEN AND B. L. PIMSTONE \\ Isotope Laboratories, Department of Medicine and MRC Nutrition Research Unit, \\ Department of Child Health, University of Cape Town, South Africa
}

(Received 27 November 1972-Accepted 20 March 1973)

\begin{abstract}
I. 'The 'big' insulin content of the serums from ten children with protein-energy malnutrition was estimated before, during and after $3-6$ weeks of treatment. The values for immunoreactive insulin (IRI) after intravenous injections of glucose were almost normal, with one exception, although tolerance was impaired. In addition, total body potassium content (TBK) was measured for three of the children on each test day.

2. In nine of twenty-three estimations 'big' insulin content was slightly more than $20 \%$ of the total IRI. However, thcre was a wide fluctuation in the values and no change was noted after treatment.

3. The amount of "big' insulin did not correlate with either the magnitude of insulin secretion, the insulin:glucose ratio or TBK. There was a barely significant negative correlation between 'big' insulin content and degree of glucose intolerance, with some individual exceptions.
\end{abstract}

Impaired glucose tolerance in subjects with protein-energy malnutrition (PEM) is usually associated with a diminished insulin secretion in response to glucose loading (Becker, Pimstone, Hansen \& Hendricks, I971). However, in a small number of cases, insulin levels are quantitatively normal or marginally subnormal and are sustained for a prolonged period after the glucose load (Becker, Pimstone, Hansen, MacHutchon \& Drysdale, 1972). This pattern of glucose intolerance in the face of an apparently adequate or even raised total insulin secretion may, among other reasons, be attributed to the secretion of large amounts of the insulin precursor, pro-insulin, which crossreacts in the insulin-assay system but exhibits a poor glucose-lowering effect (Rubenstein, Steiner, Cho, Lawrence \& Kirsteins, I 969). This possibility was examined. Proinsulin has a larger molecular weight than insulin and may be separated from it by Sephadex fractionation and assayed as the 'big' insulin of Gorden \& Roth (1969). 'Big' insulin was estimated in the serums of malnourished children, who, with one exception, had shown either quantitatively normal values for peak insulin or sustained insulin release in the face of abnormal glucose tolerance. Results showed that there was no excessive secretion of 'big' insulin. Fluctuation within the accepted normal range may have been related to glucose intolerance in this situation, but this was barely statistically significant.

\section{EXPERIMENTAL}

Case material

Ten children, aged I-4 years, with PEM were admitted to the Metabolic Unit of the Red Cross Children's Hospital, Cape Town. All were suffering from kwashiorkor 
and were under weight, with oedema and associated hypoalbuminaemia. Dermatosis was a frequent feature. They were given a protein-free diet containing at least Io $\mathrm{g}$ carbohydrate/kg body-weight for $24 \mathrm{~h}$ before testing, and were given appropriate antibiotics, potassium chloride and vitamins. Informed consent was obtained from the mother in each case.

\section{Methods}

All ten patients received intravenous injections of glucose ( $1 \mathrm{~g} / \mathrm{kg}$ body-weight of a $250 \mathrm{~g} / 1$-dextrose solution) over $2 \mathrm{~min}$. Blood samples were obtained by venepuncture before and 5, 20, 45, 60 and $9 \circ \mathrm{min}$ after the glucose load. In two of the patients the glucose tolerance test (GTT) was repeated $24 \mathrm{~h}$ later, during which time they had been given an infusion of $20 \mathrm{~g}$ of an amino acid solution (Amigen; Saphar Laboratories Limited, Cape Town). The GTT was repeated on an additional four patients 4-6 d after they had been given milk feeds. Seven of the ten children were again tested after $3^{-6}$ weeks of nutritional replacement, at a stage of clinical and biochemical recovery. A total of twenty-three studies were performed.

Blood glucose was estimated by the method of Somogyi-Nelson (Somogyi, I952). Serum was separated immediately and frozen until immunoreactive insulin (IRI) was estimated by radioimmunoassay (Morgan \& Lazarow, I963) with porcine insulin (Novo Laboratories, Copenhagen) as a standard and radioactive tracer, and guineapig-antiporcine insulin serum (Batch no. K9223; Wellcome Reagents Limited, Beckenham, Kent). The antiserum was show'n to have good immunological crossreactivity with porcine pro-insulin (kindly donated by Dr L. Heding, Novo Laboratories, Copenhagen) although binding was not as strong as that of porcine-insulin standard ('big' insulin:insulin, $\mathrm{x}: 2 \cdot 5$ ), as has been reported by Roth, Gorden \& Pastan (I968) with a different antiserum. After the amounts of IRI had been estimated, equal volumes of the serums taken at 5, 20, 45,60 and 9o min were pooled and applied to a Sephadex G-50 column for fractionation by the method of Gorden \& Roth (Ig69). Discrete IRI peaks corresponding to 'big' and 'little' insulin fractions were resolved. The amount of 'big' insulin recovered was related to the total IRI recovered in the eluate which was obtained by combining IRI contents associated with the 'big' and 'little' peaks. Total body potassium content (TBK) was calculated from estimates of the naturally occurring isotope ${ }^{40} \mathrm{~K}$ which were made with a Packard whole-body counter (Mann, 1972). In three cases estimates were made immediately before each GTT.

The glucose disappearance-rate constant $\left(k_{\mathrm{G}}\right)$ was calculated as $0.693 \% \div T_{\frac{1}{2}} / \mathrm{min}$, where $T_{\frac{1}{2}}=$ the half disappearance time (min) on semilogarithmic plotting of serial total blood-glucose values after glucose infusion (Ikkos \& Luft, 1957). The values for insulin and glucose were plotted arithmetically and the insulin:glucose ratio was calculated as the area under the insulin curve determined with a planimeter divided by the area under the glucose curve. 
Table I. Serum immunoreactive insulin (IRI) levels during intravenous glucose tolerance tests, 'big' insulin content expressed as a percentage of IRI in the pooled serum samples, glucose disappearance rate constant $\left(\mathrm{k}_{Q}\right)$, serum albumin content and total body potassium content $(T B K)$ in ten patients with protein-energy malnutrition

\begin{tabular}{|c|c|c|c|c|c|c|c|c|c|c|c|c|}
\hline \multirow[b]{3}{*}{ Subject } & \multirow[b]{3}{*}{ Treatment } & \multirow{3}{*}{$\begin{array}{c}\text { Serum } \\
\text { albu- } \\
\text { min } \\
(\mathrm{g} / \mathrm{l})\end{array}$} & & & & & & & \multirow{3}{*}{$\begin{array}{c}\text { 'Big' } \\
\text { insu- } \\
\text { lin } \\
\text { as } \% \\
\text { IRI }\end{array}$} & \multicolumn{2}{|c|}{ TBK } & \multirow[b]{3}{*}{$k_{\mathrm{G}}$} \\
\hline & & & \multicolumn{6}{|c|}{ Serum IRI $(\mu \mathrm{U} / \mathrm{ml})$} & & & & \\
\hline & & & $\circ$ & 5 & 20 & 45 & 60 & 90 & & equiv. & $\mathrm{kg}$ & \\
\hline F.A. & Untreated & 10.8 & 7 & 12 & 29 & 22 & & 2 & ० & - & - & I. 82 \\
\hline & & $35 \cdot 1$ & 8 & 126 & II & 10 & 8 & 8 & 12 & - & — & 3.30 \\
\hline M.M. & Untreated & $16 \cdot 0$ & 5 & I6 & 13 & I 5 & I 8 & 12 & 28 & - & - & $1 \cdot 26$ \\
\hline & Treat & $42 \cdot 7$ & 9 & 39 & 27 & 22 & 24 & 8 & 8 & - & 一 & $2 \cdot 10$ \\
\hline M.E. & Untr & I9. & 8 & 28 & 18 & I6 & 20 & I 8 & I7 & - & - & 0.99 \\
\hline & Tre & $38 \cdot 6$ & ro & $3 I$ & 22 & 30 & I4 & 6 & 4 & - & - & $2 \cdot 31$ \\
\hline D.J. & Untre & $12 \cdot 5$ & 4 & 2 & $2 \mathrm{I}$ & 25 & $\mathrm{I} 2$ & 3 & 26 & - & - & г 98 \\
\hline & Treated & $42^{\circ}$ & 10 & $6 \mathrm{I}$ & 38 & Io & 5 & 5 & 5 & - & - & 2.59 \\
\hline G.T. & Untreated & $I_{4} \cdot 6$ & o & 22 & 16 & ro & 12 & 2 & 16 & - & - & $I \cdot 16$ \\
\hline & $\begin{array}{l}\text { Intravenous amino } \\
\text { acids for I d }\end{array}$ & $13 \cdot 0$ & o & 38 & 20 & 12 & 14 & 7 & 18 & - & - & $I \cdot 10$ \\
\hline & Treated & - & - & - & - & - & - & - & - & - & - & - \\
\hline F.G. & Untreated & $8 \cdot 8$ & 6 & 14 & 14 & II & II & I3 & 25 & - & - & 0.77 \\
\hline & $\begin{array}{l}\text { Intravenous amino } \\
\text { acids for I d }\end{array}$ & 8 & 6 & 37 & $2 \mathrm{r}$ & I4 & 12 & $x 6$ & 26 & - & - & $I \cdot 14$ \\
\hline & Treated & $36 \cdot 6$ & Io & 62 & 25 & 13 & I7 & 8 & 26 & 一 & - & $I \cdot 98$ \\
\hline S.M. & Untreated & $20 \cdot 7$ & I & 74 & 25 & 12 & 5 & 2 & o & - & - & $2 \cdot 31$ \\
\hline & M & $28 \cdot 0$ & 7 & I 57 & 56 & 37 & 34 & 6 & 4 & - & 一 & $r \cdot 73$ \\
\hline & Treated & - & - & 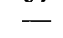 & - & - & - & - & - & - & - & - \\
\hline S.P. & Untreated & $23 \cdot 6$ & I & 50 & I7 & I & $\mathrm{r} 2$ & 8 & I & 278 & $38 \cdot 9$ & $I \cdot 35$ \\
\hline & Milk $f$ & $26 \cdot 7$ & 8 & 33 & Io & 16 & 22 & 6 & 25 & 316 & $4 \mathrm{I}^{\circ}$ & $I^{\circ} 52$ \\
\hline & Treated & 37.8 & $\circ$ & 52 & 21 & 6 & 2 & 4 & 12 & 323 & $3^{8 \cdot 8}$ & 3.00 \\
\hline A. du P. & Untreated & $29 \cdot 7$ & 2 & $7 \mathrm{I}$ & 20 & I7 & 4 & 4 & 0 & 230 & $45 \cdot 8$ & 3.05 \\
\hline & Milk for $4 \mathrm{~d}$ & 343 & I & 26 & 10 & 9 & 6 & $\mathrm{I}$ & 0 & 223 & $44^{\circ} 0$ & $2 \cdot 20$ \\
\hline & Treated & & - & - & - & 一 & - & - & - & - & - & - \\
\hline J.S. & Untreated & II'O & & 6 & 4 & 4 & 2 & 3 & $4 \mathrm{I}$ & 2280 & $33 \cdot 9$ & $I \cdot 04$ \\
\hline & & $2 \mathrm{I}$. & 6 & 48 & 32 & 30 & 30 & ro & 27 & 253 & $3^{8 \cdot I}$ & $x \cdot 55$ \\
\hline & Treated & 375 & 6 & 69 & $4 I$ & 25 & II & 6 & $3^{\circ}$ & 337 & $47 \cdot 5$ & $2 \cdot 38$ \\
\hline
\end{tabular}

\section{RESULTS}

Table I shows IRI content of serum samples from the subjects during intravenous glucose tolerance tests as well as values for 'big' insulin content expressed as a percentage of the total IRI content of the pooled serum samples, $k_{\mathrm{G}}$ and TBK values, before, during and after treatment for the ten children.

Glucose tolerance was abnormal because $k_{\mathrm{G}}$ was less than $2 \cdot 0$ (Loeb, I966) in eight of the ten patients examined before treatment. Of these eight, five had an IRI content of more than $20 \mu \mathrm{U} / \mathrm{ml}$ (taken as the lowest limit for normal subjects) (Becker $e t$ al. I97I), and in a further two patients insulin concentrations were subnormal but sustained. Thus in seven of the eight patients with impaired glucose tolerance, insulin secretion was quantitatively normal or sustained.

In one patient only, the 'big' insulin content was more than $30 \%$ of the total plasma IRI, and this was the only patient with low insulin concentrations for whom accurate 
Table 2. Correlation between the 'big' insulin (expressed as a percentage of total immunoreactive insulin) and glucose disappearance rate constant $\left(\mathrm{k}_{G}\right)$, area under the immunoreactive insulin curve, insulin: glucose ratio, total body potassium content (TBK) and serum albumin in ten children with protein-calorie malnutrition

\begin{tabular}{lccc}
\multicolumn{1}{c}{ Measurement } & $\begin{array}{c}\text { Correlation } \\
\text { coefficient }\end{array}$ & $P$ & $\begin{array}{c}\text { No. of } \\
\text { estimates }\end{array}$ \\
$k_{\mathrm{G}}$ & -0.45 & $<0.05$ & 23 \\
Insulin area & -0.232 & $>0 . \mathrm{I}$ & $2 \mathrm{I}$ \\
Insulin:glucose ratio & -0.343 & $>0 . \mathrm{I}$ & $2 \mathrm{I}$ \\
TBK (mequiv./kg) & -0.396 & $>0 . \mathrm{I}$ & 8 \\
Serum albumin $(\mathrm{g} / \mathrm{l})$ & $-0.38 \mathrm{r}$ & $<0 . \mathrm{I}$ & 23
\end{tabular}

estimation of the 'big' insulin fraction was therefore difficult. However, nine of the twenty-three estimates of 'big' insulin content made in untreated or treated cases were greater than $20 \%$ of the total IRI. Eight of these nine results were associated with $k_{\mathrm{G}}$ values lower than 2. Of interest in this context was patient F.G. for whom the proportion of 'big' insulin remained high $(26 \%)$ and was associated with a persistently abnormal $k_{G}$ value even after therapy. On the other hand, in some of the children, similar low values for $k_{\mathrm{G}}$ were associated with a 'big' insulin content which was less than I0\% of the total IRI, and in one patient (J.S.) the $k_{G}$ value returned to normal but the 'big' insulin content remained raised at $30 \%$. There was, however, a statistically significant negative correlation between 'big' insulin content and $k_{\mathrm{G}}$ when all the estimations were considered (Table 2).

The 'big' insulin values obtained before and after treatment varied and showed no consistent change in response to feeding, unlike the values for insulin secretion which tended to increase. Correlation coefficients between the percentage of 'big' insulin and either the area under curve for insulin, or insulin: glucose ratio, were not significant (Table 2).

TBK was low, and rose after treatment in two of the three patients. A fuller analysis of this and more extensive results for TBK will be the subject of a separate communication. In the patients for whom 'big' insulin content and TBK were estimated simultaneously, there was no correlation between the measurements (Table 2).

\section{DISCUSSION}

Pro-insulin is now accepted as the immediate biological precursor of insulin and has been isolated from the human pancreas (Rubenstein, Cho \& Steiner, 1968) and commercial insulin (Steiner, Hallund, Rubenstein, Cho \& Bayliss, I968). It has been shown to correspond with the 'big' insulin identified by Gorden \& Roth (1969) and to show some immunological identity with insulin, but is of a larger molecular weight (Roth et al. 1968; Gorden \& Roth, 1969). Although this precursor of insulin crossreacts well with insulin antiserums and can therefore be estimated as IRI, it has been shown to exhibit poor biological function (Chance, Ellis \& Bromer, 1968; Fineberg \& Merimee, 1970 ). Therefore, an excessive proportion of circulating pro-insulin or 'big' insulin was thought to account for certain states of glucose intolerance associated with 
apparently adequate IRI secretion, for example in maturity-onset diabetes, but was found to be normal (Roth et al. I968; Goldsmith, Yalow \& Berson, I969; Gorden \& Roth, 1969). Secretion of 'big' insulin appears to increase only in islet-cell tumours (Roth et al. 1968; Goldsmith et al. 1969; Lazarus, Tanese, Gutman \& Recant, I970) and K-deficiency states (Gorden, Sherman \& Simopoulos, I972).

The formation of insulin from pro-insulin in the pancreas is achieved by cleavage of a peptide chain by proteolytic system(s). Many enzymes are deficient in PEM, including pancreatic trypsin (Barbezat \& Hansen, 1968); therefore there may be an abnormal proportion of 'big' insulin in children with this disorder.

No values are available for ' big' insulin in children and the division between normal and abnormal amounts is undefined. The position in adults, too, is not clear as a proportion of 'big' insulin greater than $20 \%$, relative to total IRI, is considered excessive by Goldsmith et al. (1969); on the other hand, values of up to $30 \%$ have been considered normal (Roth et al. 1968). However, quantitative estimation of 'big' insulin content is complicated by variations in the cross-reactivity of different antiserums against pro-insulin standards (Gorden \& Roth, 1969). Furthermore, there is evidence that the percentage of 'big' insulin relative to total IRI may change during the course of insulin secretion after glucose loading (Roth et al. I968; Gorden \& Roth, I969). Unfortunately, as a relatively large volume of blood is needed for each 'big' insulin assay, the percentage of 'big' insulin could only be estimated for pooled serums. In nine of twenty-three measurements for these children the percentage of 'big' insulin exceeded $20 \%$ relative to total IRI and only one of these values was over $30 \%$. This value may have little relevance as it was found in the single patient with very low amounts of total insulin. The proportion of circulating 'big' insulin in PEM was, therefore, within the range reported for normal adults, but in many cases was at the upper limits of that range. It is, nevertheless, below the figures associated with insulinoma.

Although values were at the upper limit of the normal range in nine instances, the amount of 'big' insulin is unlikely to have important pathological significance, as it remains unaltered in some of our cases after treatment, when insulin:glucose ratios and 'insulin areas' had improved. Some patients showed low 'big' insulin values, having abnormal glucose tolerance, and others (J.S., post-treatment) showed values at the upper limits of the normal range but had normal glucose disposal. Nevertheless, an inverse statistical relationship between $k_{\mathrm{G}}$ and 'big' insulin content was obtained when results from all the tests were considered together, but this was only significant at the $5 \%$ level. Although unlikely, it is possible that a higher proportion of 'big' insulin (within the accepted normal range) could be one of the factors causing glucose intolerance in situations where insulin secretion appears adequate. As plasma samples were pooled, significant changes may have been missed. Only the radioimmunoassay of human pro-insulin with individual blood samples during glucose tolerance in PEM will resolve this point.

It has recently been shown that both experimental $\mathrm{K}$ deprivation and diseases associated with $\mathrm{K}$ deficiency are accompanied by an increase in the proportion of 'big' insulin associated with the IRI response to glucose (Gorden et al. I972). Our 
results showed no relationship between 'big' insulin content and TBK. This observation is particularly relevant as the TBK associated with untreated PEM is low but increases when subjects are given $\mathrm{K}$-supplemented diets and is closely related to the total IRI responses to glucose (Mann, 1972). However, in PEM, TBK is not always associated with hypokalaemia and reflects not only potassium deficiency but lean body mass, a variable not present to the same extent in the patients of Gorden et al. (1972).

This study was supported by grants from the US Public Health Service AMO-3995, South African Medical Research Council, South African Atomic Energy Board and Wellcome Trust. Thanks are due to Dr M. Mann for measurements of total body K and the performance of GTT on three patients.

\section{REFERENCES}

Barbezat, G. O. \& Hansen, J. D. L. (1968). Pediatrics, Springfield 42, 77.

Becker, D. J., Pimstone, B. L., Hansen, J. D. L. \& Hendricks, S. (I97I). Diabetes 20, 542.

Becker, D. J., Pimstone, B. L., Hansen, J. D. L., MacHutchon, B. \& Drysdale, A. (1972). Am. F. clin. Nutr. 25, 499.

Chance, R. E., Ellis, R. M. \& Bromer, W. W. (1968). Science, N.Y. r6r, I65.

Fineberg, S. E. \& Merimee, T. J., (1970). Science, N.Y. I67, 998.

Goldsmith, S. J., Yalow, R. S. \& Berson, S. A. (1969). Diabetes x8, 834.

Gorden, P. \& Roth, J. (1969). Archs intern. Med. 123, 237.

Gorden, P., Sherman, B. M. \& Simopoulos, A. P. (I972). F. clin. Endocr. Metab. 34, 235.

Ikkos, D. \& Luft, R. (1957). Acta endocr., Copenh. 25, 3 I2.

Lazarus, N. R., Tanese, T., Gutman, R. \& Recant, L. (1970). F. clin. Endocr. Metab. 30, 273.

Loeb, H. (1 966). \%. Pediat. 68, 237.

Mann, M. D. (1972). Potassium in young children. PhD Thesis, University of Cape Town.

Morgan, C. R. \& Lazarow, A. (1963). Diabetes r2, I I5.

Roth, J., Gorden, P. \& Pastan, I. (1968). Proc. natn. Acad. Sci. U.S.A. 61, 138.

Rubenstein, A. H., Cho, S. \& Steiner, D. F. (1968). Lancet i, т353.

Rubenstein, A. H., Steiner, D. F., Cho, S., Lawrence, A. M. \& Kirsteins, B. S. (1969). Diabetes r8, 598. Somogyi, M. (1952). F. biol. Chem. r95, r9.

Steinet, D. F., Hallund, O., Rubenstein, A., Cho, S. \& Bayliss, C. (1968). Diabetes r7, 725. 